\title{
»Vulnerable Families«: Reflections on a Difficult Category
}

Petra Bauer $^{* 1}$ And Christine Wiezorek ${ }^{2}$

$\approx$ The term "vulnerable families" refers to familial living situations that are considered problematic, with a particular need for socially responsible, professionally provided support. This means of categorising families is extremely ambivalent, indicating not only a need for society to support forms of family life and family achievements, but also a particular need to protect children growing up within the family. It also has implications for an understanding of interventions geared to the riskiness of family living situations and their standardisation, an understanding that risks losing sight of families' variety and individual peculiarities. Families in need of support have a fundamental right for their individuality and parenthood to be recognised. A detailed case analysis of a social worker who is working with a family in which a child's wellbeing is at risk shows how transferring standardising ideas about the family can damage that basic right. The article thus calls for the category of vulnerability to be applied to families with reflection on the specific case and on implicit normative leanings.

Keywords: vulnerability, child protection, family image, family concept, social work, family support

1 *Corresponding Author. Eberhard-Karls-Universität Tübingen, Deutschland; petra.bauer@unituebingen.de.

2 University of Gießen, Deutschland. 


\section{»Ranljive družine« - refleksija o zapleteni/težavni opredelitvi}

Petra Bauer in Christine Wiezorek

$\propto$ Termin "ranljive družine« se nanaša na družinskobivanjske situacije tistih družin, ki so ocenjene kot problematične; te terjajo družbeno odgovorno in strokovno utemeljeno podporo. To pomeni, da je kategoriziranje takšnih družin samo po sebi ambivalentno, saj hkrati kaže na potrebo po strokovno odgovornih in hkrati celovitih podporah takšnim družinam, obenem pa tudi potrebo po subtilnem prepoznavanju njihovih dosežkov. Ob tem je hkrati treba primerno zaščititi otroke, ki odraščajo v okviru takšne družine. Opredeljevanje družin kot ranljivih ima prav tako posledice za razumevanje strokovnih posegov; ti morajo biti prilagojeni tveganosti življenjskih razmer družine, hkrati pa nekaterim njenim splošnim značilnostim, pri čemer se je dobro zavedati, da lahko spregledamo raznolikost družin in tudi njihove individualne posebnosti. Ta podrobna vsebinska analiza poteka dela socialne delavke, ki dela z družino, v kateri je ogrožena blaginja otroka, kaže, kako lahko prenašanje posplošenih idej o družini ogrozi to osnovno pravico. Prispevek zato poziva, da se uporaba opredelitve »ranljivost« opre na razmislek o posameznem primeru družine in implicitna normativna pričakovanja.

Ključne besede: ranljivost, varstvo otrok, družinska podoba, družinski koncept, socialno delo, družinska podpora 


\section{Introduction}

The term "vulnerable families" refers to families ascribed a particular need for support. In German, the categories that relate to vulnerable families, or that are translated as "vulnerable families", extend from "sozial schwach", "gefährdet", "bedürftig" and benachteiligt" (socially weak, at risk, in need and disadvantaged), to "verletzlich", "in Not geraten" and "hilfsbedürftig" (vulnerable, in difficulty and requiring support). Here, the category of vulnerability is aimed in different ways at the family's responsibility for caring for and raising children, as well as at how family members support and care for one another. This makes it clear that, in the conditions of our changing modern society, the family can evidently not (or can no longer) fulfil its socialising duties unquestioningly and as a matter of course. As a whole, the family thus comes across as particularly vulnerable or at risk with regard to its social functions. ${ }^{3}$ Categorisations of "social weakness", neediness, vulnerability, disadvantage or "children at risk" are used in various ways to identify deficits that society needs to deal with (e.g., Hasselhorn et al. 2015), especially as familial reproduction appears to be at risk when it comes to educating and raising children in a socially acceptable manner.

On the one hand, these categorisations thus link in with the discourses that developed at the start of the $20^{\text {th }}$ century (with an increasing emphasis on children's rights and child protection) on children's particular need for protection and the support they require when growing up (Honig, 1999; Lenz \& Böhnisch, 1997; Zenz, 1979); on the other hand, they also form the basis for the increasing "discovery" of the risks involved in growing up within families, which has drawn institutional and professional attention to families not only as socially necessary places of shelter and protection, but also as a potential threat and risk to positive childhood development (Bauer \& Wiezorek, 2007; Wiezorek \& Pardo-Puhlmann, 2013; Wilhelm, 2005). From the variety of special needs strategies, early years programmes and resilience-building schemes that have now systematically colonised childcare and school (Andresen, Koch \& König, 2015), the emphasis on children's vulnerability and the risks to which children are thought to be subjected as they grow up would currently seem to be particularly popular. As another example, the reorganisation of legal child protection measures involved an early years support system ("Frühe Hilfen") being established in Germany, which proactively reaches out to families in the

3 This can also be seen from the fact that families are described as vulnerable, whereas schools are not. However, the question as to how effectively schools can and do fulfil their social task of education and childraising can, in fact, frequently be asked. 
first three years after their children's birth, offering advice and help. This new, developing support system is aimed precisely at families' socially expected "vulnerability", especially in the early stages of the family. In view of the clear bias towards child protection work, its conception can, on the one hand, be read as expressing a perceived increase in public responsibility for children's upbringing; on the other hand, the early years support system always also gives the professionals involved the task of protection: during this stage, at which young children are not yet integrated systematically into any pedagogical institution, these forms of support provide a means of access to families that can be used to recognise child neglect and abuse at an early stage (Bauer, 2016). Here, too, the family is addressed as a place where children are potentially at risk (Helming, 2010). On the linguistic level, this is manifested in terms used widely in the field, such as "early warning system" or "high-risk family", expressions of an "investigative" understanding of intervention with technological connotations (ibid., p. 177). These terms reveal an approach to families that basically sees all families through a veil of suspicion (Hildenbrand, 2011). Dekker (2010) has also shown that the currently dominant aspiration to provide "better care for more and more children" exists in two versions, which, viewed in a historical perspective, do not contradict each other. The manifold efforts to enforce children's right to education are always accompanied by the "discovery" of an increasing number of "vulnerable" children. In this context, it is above all the family that appears to be a potential risk to the future prospects of their children, who, in turn, are seen as a potential risk for the future and for social cohesion (Hübenthal \& Ifland 2011; Turnbull \& Spence 2011).

Altogether, categorising families as vulnerable can be seen to have a paradoxical effect. In a rather casual, unreflecting manner, this categorisation increasingly seems to evoke images of families in which it is now the families themselves, rather than conditions of social inequality, that pose a potential threat to children's upbringing. Our main thesis, however, is that this also generally damages people's recognition of family integrity, i.e., everything that society should particularly be protecting; ${ }^{4}$ in other words, it makes the family all the more vulnerable (Featherstone, Morris \& White, 2014).

From the pedagogical point of view of the family, especially, the category of "vulnerable families" seems "susceptible" to making the family even more vulnerable through generally categorising approaches. This thesis is related to various research results that show the ways and effects of categorisation in professional work with families. Thus, in various studies, White et al. (White,

4 Section 6 (1) of the German constitution thus postulates that "Marriage and the family shall enjoy the special protection of the state". 
2003; White \& Wastell, 2010) elaborate the fact that professional judgements on problems are based on specific ideas about parenthood and childhood. Professionals see childhood as a time of fragility, passivity and also honesty, meaning that when professionals are actually working with families, they generally give greater credibility to children's stories about what goes on in their families than to parents' descriptions. "This privileging of the child's voice, combined with ironizing parents' versions, results in social workers working up versions of the troubles which tend to exculpate children while inculpating parents" (White $2003,179)$. Here, the question of credibility or blame - laying the blame and responsibility for problems within families - is put forward as being fundamental to social pedagogical work with families. A central role is played by assessments of the family's child-raising abilities as "good parenting", on the one hand, or "bad parenting", on the other. Both takes are said to have direct effects on children's development. It is assumed that maternal and parental love is basically natural, but this is something that is quickly questioned in the case of parents who make use of professional support (Siembrouck \& Hall, 2003). If parents do not manage to portray themselves as loving, caring parents, they risk being accused of lacking basic human abilities (see also Urek, 2005). This demonstrates the central function of "normalising" everyday images of the family when constructing a professional opinion on a case, which is where the second hypothesis that the present article is intended to explain comes in. We postulate that the outlined processes by which families are categorised are structured by the images of the family held by professionals. Images of the family, understood as "socially objectified, i.e. understandings of what the family is and what it should be which are valid, or at least capable of being valid" (Bauer, Neumann, Sting, Ummel \& Wiezorek, 2015, p. 25) are based just as much on how professionals process their own family experiences as on socially and culturally conveyed concepts of the family (ibid; also: Bauer \& Wiezorek 2009; Pardo-Puhlmann 2010; Wiezorek \& Pardo-Puhlmann 2013).

We would like to use a case example to illustrate these reflections on family images and the effect they have when it comes to categorising families perceived as "vulnerable". This example comes from observation notes taken by a student. The notes were written during a teaching unit at the University of Jena aimed at reflecting on students' work placements on a case-by-case basis. In this seminar, students were asked to use qualitative surveys to reflect upon their experiences in practice (Riemann, 2010). In order to do so, they used, among other things, observation notes written during their work placement. The material gathered in these notes was reinterpreted by a research group that has been working for some time on the topic of images of the family in professional 
pedagogical practice. The method used was sequential analysis. This is therefore an individual example that is not integrated into a wider research context. The notes are an impressive document of the way in which processes of categorisation that can be summed up under the aspect of vulnerability affect interactions. However, it also shows how students (prospective professionals) see things from the point of view of the mentor, the social worker. The notes thus also offer some insights into issues surrounding professionalisation, although this point is not discussed at this juncture.

The interaction between a social worker and a mother in the context of a risk to the child's wellbeing shows specifically what we have referred to as a paradoxical effect: the family's vulnerability is increased by professional interventions, here expressed as the social worker's moralising, categorising perception of the mother.

\section{The influence exerted by ideas about the family on a social worker's actions: An example of an analysis}

A social work student's report about a home visit paid during a period of work experience on a case with a social worker in the general social services ended:

"The social worker said goodbye in a friendly way and said that she would get in touch if Marc was leaving the care home. Ms Schulze nodded and took us to the door, where she wished us a good day. As we left the block of flats, the social worker said to me that words failed her, and that she would now be doing her best to get the other two lads into a foster family, as it did not look as if the children would be returning to their mother."

This shows clearly that, at the end of the home visit, the social worker makes a decision about Marc's two brothers being taken in by a foster family. In Germany, living in a foster family, a form of full-term care, falls into the category of child-raising support offered under the law on child and youth welfare (German Social Security Code (SGB) VIII). Childraising support is one of the (family-related) services under SGB VIII: according to Section 27, Subsection 1, parents or legal guardians "have a right to support when raising a child or adolescent (childraising support) if the child or young person cannot be guaranteed an upbringing conducive to his or her wellbeing and if the support is suitable and necessary for his or her development" (ibid.).

The reasoning noted by the student as being behind the social worker's decision to try to have the two boys taken in by a foster family is related to her 
impression that "it did not look as if the children would be returning to their mother". The student notes the comment - a sign of outrage - that "words failed her" about what had evidently come to light or taken place during the visit; something that triggered the social worker's decision. The question that arises here is thus what led the social worker to the decision to try to have the "other two lads" taken in by a foster family. In order to find out, let us return to the beginning of the notes:

"On XXXX the social worker responsible for the case and I set off to visit $M s$ Schulze. The reason for the home visit was to inform Ms Schulze that her eldest son Marc was being moved into a foster family having spent several years at a children's home. Ms Schulze had to agree to this, and sign to confirm her agreement."

Here, too, the topic is a transfer to a foster family; in this case, that of Marc, Ms Schulze's eldest son. It quickly becomes apparent that Ms Schulze was not involved in the decision to relocate Marc, despite the fact that the law does actually foresee this kind of involvement. Decisions on the need, urgency and suitability of child-raising support are made as part of the support planning process set out legally in Section 36 of SGB Book VIII. ${ }^{5}$

In the case in question, however, the decision to house Marc in a foster family is revealed as a decision that Ms Schulze is simply informed about, and that only requires her to "sign to confirm her agreement": the purpose of the home visit is to retroactively legitimise a decision made without the mother who has custody - being given a say in the matter. Ms Schulze thus does not come across as a service user entitled to support and working together with providers, as set out in the regulations; instead, she is addressed here as a passive beneficiary of support for whom paternalistic decisions are being made.

5 This states, for example: "Section 36 of SGB VIII: Participation, support plan

(1) Prior to any decision on the mobilization of support and any necessary change in the type and level of assistance provided, the child or young person and their guardian must be advised of this and informed about possible consequences for the development of the child or young person. Before and during any support provided outside their own family, checks must be carried out as to whether adoption might come into consideration. If support is required outside their family, the people named in Sentence 1 shall be involved in selecting an institution or a foster family. This choice and wishes shall be complied with unless they imply any disproportionate additional costs. $[\ldots]$

(2) If support is likely to be provided for an extended period of time, the decision on the form of support which is appropriate in each case shall be taken jointly by several professionals. As the basis for selecting the support to be provided, they shall make a support plan along with the child or young person and the persons who have custody, deciding what is needed, the form of support to be provided and the services required; they shall then regularly check whether the form of support selected remains suitable and necessary. If any other people, services or institutions take part in providing the support, they or their staff shall be involved in compiling and checking the support plan." 
Her point of view regarding where her son lives does not seem to be relevant to the youth welfare department employee. This has two implications: firstly, the assumption that Marc's mother shows a lack of interest in her son, and, secondly, the assumption that she cannot make any useful contribution to Marc's upbringing.

However, as demonstrated by the fact that her signature is required, the mother evidently has custody of her son, even though he has not lived with her for several years. This implies that the mother is interested in her child or, put another way, that she is making an effort to fulfil her responsibility as a parent. The negation of this in the present case gives rise to the interpretation that the social worker perceives the mother as inherently self-centred and unwilling to raise her children. This is a violation of the mother's rights to recognition as a service user who, although in need of support and help (therefore being vulnerable), also has custody and is thus entitled to receive certain services. Viewed in this light, the social worker's categorising perception of Ms Schulze as self-centred and unwilling to raise her children provokes a further "injury" regarding Ms Schulze, as can be seen from what happens next. The allusions to Ms Schulze's living environment bolster the interpretation that the professional has a moralising, hurtful perception:

"First we entered the hallway, which was full of shoes and old cardboard boxes. It also smelt strongly of sweat throughout the flat, which the social worker had, however, told me about on the way to the flat. The social worker in charge of the case informed Ms Schulze that she would like to see the children's room, and Ms Schulze first took us into her bedroom, where the youngest of Ms Schulze's six children slept along with her foreign boyfriend. Here it should be noted that Ms Schulze is in her mid-twenties."

As well as the note on how messy the flat is (a recurrent theme in the continuation of the report), it is the comment that Ms Schulze's boyfriend is not of German origin and that she already has six children in her "mid-twenties" that the report-maker also uses to make an implicit moralising evaluation of Ms Schulze's living environment. The messiness, Ms Schulze's partner's background and the number of children, especially considering the woman's age, are turned into proof of the family's lack of effort in childraising and the need to monitor the family. In this respect, the monitoring approach taken by the social worker in charge of the case - as expressed in the wish to start out by seeing the children's room - does not come across to the student as needing further justification.

What is interesting is that throughout the visit, according to the notes, Ms Schulze complies with the social worker's requests: she goes to meet the two 
visitors in the building before they have even rung the bell; she shows them the children's room on request; she answers the social worker's questions and gives her the signature she requests, and she says goodbye in a polite manner by wishing them "a good day". After the visit, the social worker nonetheless comes to the decision that two other sons who are also in the home, along with Marc and a daughter, at the time of the conversation should be taken on by a foster family.

As the notes go on to record, the trigger for this decision is when Ms Schulze tells them shortly before they leave that:

"she was pregnant for the seventh time and was thus about to move into a bigger flat. She also said that she and her boyfriend were planning to get married the following month."

The social worker obviously has some strong emotions at this point: she "took a deep breath" and said to the student that "words failed her". Basically, the mother's news cannot be seen impartially or understood, being ambivalent, as a possible expression of her trying to "normalise" her home circumstances, or an expression of her yearning for "normal family life". The social worker evidently only sees Ms Schulze's latest pregnancy as another indication of her lack of responsibility, as four of the six children are already living out of the home. The marriage and the move, which indicate that Ms Schulze is attempting to stabilise family circumstances in the long term, appear to be irrelevant to the social worker's evaluation of (future) family circumstances; she makes the decision to "try to get the other two lads into a foster family". This demonstrates the powerful influence of the normative notions of the family held by professionals: they lead to an ad-hoc decision on a future intervention regarding the family. It is clear that these normative notions about the family are already restricting the diagnostic perspective of the family: an interpretation in which Ms Schulze, despite needing support, is also a mother attempting to take on responsibility for childcare is no longer within the realms of her diagnosis of this case.

In this context, the view of the foster family sketched by the social worker is also interesting; they are presented in a similarly moralising manner as a "good" family. We thus learn from the notes that:

"The social worker informed Ms Schulze that the reason for today's visit was that her eldest son was to be taken in by a foster family, and that they [the foster family; P.B.; C.W.] had also stated that they were prepared to take the boy's little sister out of the home after a year, as the two had a close relationship and the foster parents did not want to separate them in the long term. [...] After a questioning glance and a brief silence, the social worker handed Ms Schulze the necessary form. She also told Ms Schulze 
that the foster parents were very nice and lived in a big house with a garden; that the children also liked the foster parents a lot and were always pleased when they came to visit them at the home once a week. Ms Schulze signed the form and gave it back to the social worker, who then asked if Ms Schulze had any other questions. She looked down at the ground and replied 'no'. The social worker shook her head in disappointment and started putting her things together."

To begin with, this again makes clear that the home visit was only to inform the mother and retroactively legitimise the decision to find Marc a foster placement; it was not about the mother taking part in the decision-making process. This also applies to Marc's younger sister, who, it has already been decided, will be moving to the foster family. The picture is then painted of the "good foster family": the foster parents are highly committed, fond of the children (who return that fondness) and can provide a stimulating, generously sized living environment. They come across as the truly responsible, committed parents: firstly, they come to visit the children "once a week"; secondly, they later want to take Marc's sister into foster care; thirdly, this decision is based on the "close relationship" between the siblings; fourthly, the two children have already built a relationship with the foster parents and are "always pleased"; and, finally, the foster parents have a "big house with a garden". In other words, the mother is painted a picture of a family that is simply nothing like the children's family of origin.

The fact that Ms Schulze looks down at the ground and replies in the negative when asked if she has further questions could be diagnosed as an expression of her own shame and her perception of being put to shame: this could be understood as meaning that the mother was severely alienated by the description of the foster family as a "good family". After all, the portrayal of the "good" foster family confronted Ms Schulze with the ideal of a family and a manner of childraising that she herself is not able to live up to. In this interpretation, lowering her gaze and looking down at the ground could thus be seen as an expression of Ms Schulze's feeling hurt: a clear confrontation with the fact that her own family life is not a success, which is in any case a constant aspect of everyday life, as the four children are in out-of-home care, and thus not present. The radical demonstration of her own inadequacy inherent to the description of the foster family evidently touches a "sore spot" for Ms Schulze, and her only "response" can be to lower her gaze.

Thus, from the point of view of vulnerability, this shows how the social worker's moralising perception further "hurts" the client. These notions cancel out any interpretation of Ms Schulze as a mother who is both in need of support 
and trying to achieve a normal family life while also (somehow) taking responsibility for raising her children. Instead, the social worker (and the note-taker) see her downwards gaze and negative response as proof of her lack of interest in the two children; in turn, the social worker makes her thoughts clear by shaking her head. This, too, can be understood as an indication that the social worker's view of Ms Schulze is restricted by her own normative notions about the family, which also makes it hurtful: the social worker's understanding does not allow for the possible interpretation that the mother's reaction might actually be a sign of resignation or acknowledgment of guilt from being confronted with the idea that there are probably "better parents" for her children, meaning that the social worker's confrontation is "painful" for Ms Schulze.

Apart from the route taken by the specific action in this case, the dichotomising perception that it expresses of the family of origin as a "bad family" and the foster family as a "good family" also has a structural cause: out-of-home care would, after all, not be necessary if the childraising in the family of origin was "good enough". At the same time, however, the dichotomisation that the social worker creates in this interaction sequence, with the family of origin as bad and the foster family as good, means that the blame is implicitly laid on the family of origin, making it difficult to come up with an appropriate diagnosis of the support required, especially by the children. It can also be seen that, ultimately, family relationships are seen as exchangeable, which is not in fact the case in this example, as can be seen from the need to "ask for" a signature.

Even though - or perhaps because - this example, in the form of a student's work experience notes, focuses entirely on one social worker (whom the student evidently does not question), it reveals the problems inherent in the automatic, unreflected use of notions about the family. These obviously have an influence, restricting the social worker's diagnostic view of Ms Schulze, which is in turn (unintentionally) accompanied by further injury to the family and, finally, leads in this case to a specific ad-hoc intervention: the two young children in out-of-home care are to be taken in by a foster family.

In summary, the example of the student's observation notes sheds light, on the one hand, on how notions, interpretations and assumptions about what is normal to families affect interactions with and perceptions of specific families; on the other hand, it draws attention to how, when this view of the family is witnessed and experienced (mimetically) in practice, it is passed on to the student by the professional, almost as a form of expertise. This case example is thus not just a one-off empirical example of how notions and interpretations about the family can influence social pedagogical diagnosis and active intervention, but also an empirical "lesson" about how professionals in the making become 
acculturated during work experience by automatically, unquestioningly adopting the images of the family held by "veteran" professionals as the basis for their own reports.

\section{Pedagogical links to the family: From considering the family's vulnerability to accusing the family of hurting the child}

For the pedagogical view of the family, the category "vulnerable families" evidently seems to be a pattern of interpretation used to unite various, sometimes contradictory views of the family. An approach to the family that (as in the above example) perceives families and judges family practices against the background of what may be idealised family "normality" runs the risk of making the family even more vulnerable by acting in a generalising, categorising manner. The general conclusions that Böllert (2012) comes to regarding early years support also apply in the case set out here: the problems facing families, and especially parents, should be seen as "an expression of structurally produced needs for support" (ibid., p. 129) and not as the result of a drop in a family's performance.

Here, too, it is therefore necessary in future to take into consideration or underline the particular vulnerability of families caused by their socioeconomic positioning within society, by taking a case-sensitive approach to each family. However, if we follow Helsper (2004) in seeing professional pedagogical practice as basically interactive (asymmetrical) mediation between case assessment and rule-based knowledge, this calls for reflection on our own notions about the family.

The structural change in working patterns, gender relations and the balance between public and family childraising has now exposed such a plurality of forms of family life that one-dimensional notions of how a family is and should be made up can no longer truly do justice to the variety of possible arrangements. One result of these processes of social and cultural pluralisation is that they also "shatter the certainty and certainties of pedagogical practice" (Helsper, 2004, p. 31). Automatic pedagogical recourse to notions of a normal (bourgeois) family, which can be expected to perform family child-raising functions as a matter of course, can also be understood as an example of this loss of certainty (Bauer, Neumann, Sting, Ummel \& Wiezorek, 2015; Ummel, Bauer \& Wiezorek, 2013).

What does this mean for the pedagogical relationship to the family? "Practising professional social pedagogues", concludes Helsper (2004, p. 23) with 
regard to pedagogical practice facing cultural pluralisation, "are increasingly unable to make children and young people - let alone adults in continuing education, re-entering education or retraining - conform to certain values, principles or ways of living. Instead, practising professional pedagogues are replacing a particularist attitude to childraising with a universalist outlook of making different ways of life possible, with the prospect of a 'post-traditional' form of recognition; an educational theory of enabling 'diversity' and plurality" (ibid.).

This is a reminder of the ethical obligation of professionals to adopt the specific attitude of recognising diversity. According to this, families (or groups of families) cannot simply be labelled "vulnerable" as a subsumptive classification within a category identified by specific characteristics; instead, it calls for a case-sensitive approach to the family. In terms of professional theory, this is based on mediating between inductive case assessment and deductively drawing upon rule-based knowledge. The category of "vulnerable families" can be considered part of such rule-based knowledge, but one that should only be used in specific cases based on the context.

Our considerations thus raise the question of the role played by pedagogues' notions or images of the family generated through experience in their lifeworld. The analysis of this case shows that the social worker's normative notions of the family had a strong influence in terms of the decisions she made as a responsible professional: they were an argumentative means of justification with regard to the character of her tasks and were of clear diagnostic relevance.

It is, moreover, likely that these notions also lessened the pressure of what might have been a heavy workload or high expectations (by others or herself): automatically taking recourse to images of the "good" family can reduce the variety and complexity of thinking processes about the family and parenthood, in turn allowing the social worker to access her knowledge about families in a rapid and, unsurprisingly, subsumptive manner. However, as a recent study on programmes organised by child protection services in Germany shows (Bühler-Niederberger et al. 2014), you can also see the social worker's attitude and interventions in the case study as part of a professional programme that is typical of social workers working in the field of child protection. In their comparison of different professional approaches, Bühler-Niederberger et al. determine that social workers primarily address the mothers when they are talking about their work with families. They also show how social workers address mothers in the manner of morality and with the goal of intervening in their way of life. In social workers' view, parenting is still reduced to motherhood and the behaviour of the mother; there is therefore a risk of losing sight not only of the importance of fatherhood but also of the child's wellbeing. 
Against this background, the present case - with the mother being shamed and the ad-hoc decision about two of her children being taken into future foster care - also reveals the "pitfall" of this kind of unreflected recourse to one's own notions of the family in the sense of motherhood. This calls for reflection, explication and systematisation of the knowledge about the family that social workers acquire in everyday life and through experience.

The first change that seems necessary here is greater reflection on social workers' view of the family, paying greater attention to "how individual developments within the family depend upon one another and on the (individual) structure of each family" (Zenz, 1979, p.69). If the logic behind social pedagogical interventions mainly consists of addressing the mothers, there is a risk of losing sight of the mutual effects of family interactions and their interplay within the family as a system (Bauer \& Wiezorek, 2007).

The second change would be to add to social workers' knowledge about families and the diversity of families' situations in life. Taking recourse to the category of "vulnerable families" and the knowledge acquired under this label about specific problems faced by families, and effective means of support, can absolutely be seen as an expression of this kind of scientisation of the pedagogical approach. At the same time, taking recourse to the socio-scientific category of "vulnerable families" does not necessarily guarantee that the pedagogical approach to the family will be case sensitive. Instead, it risks creating an individualising, implicitly blame-apportioning approach to families, which threatens to alter perceptions of the structural conditions of their living conditions, their ways of life and the conditions of inequality these imply (Featherstone, Morris \& White, 2014; White \& Wastell. 2011).

When it comes to pedagogical practice, there is thus a need to make family vulnerability a criterion of a case-sensitive approach to families, in order to avoid generating paradoxical effects (Hildenbrand, 2011). It is only with reflection on related normative notions about the family that we can help families (including vulnerable families) in their efforts to raise their children and break down what may be unequal social structures rather than reproducing them (Hall \& Slembrouck, 2011; White \& Wastell, 2011). To this extent, the category of vulnerable families can thus be used effectively if it specifically serves to address families' structural need for support and to guarantee that they will actually receive the support they need in each specific case. 


\section{References}

Andresen, S., Koch, C., \& König, J. (2015). Kinder in vulnerablen Konstellationen. Zur Einleitung [Children in vulnerable constellations. Introduction]. In S. Andresen, C. Koch, \& J. König (Eds.), Vulnerable Kinder. Interdisziplinäre Annäherungen [Interdisciplinary approaches] (pp. 7- 9). Wiesbaden: Springer; VS.

Bauer, P. (2016). Förderung der Erziehung in der Familie [Advancement of family education]. In W. Schröer, N. Struck, \& M. Wolff (Eds.), Handbuch Kinder- und Jugendhilfe (2nd ed.) [Handbook of Youth Welfare] (pp. 866-912). Weinheim; Munich: Beltz.

Bauer, P., \& Wiezorek, C. (2007). Zwischen Elternrecht und Kindeswohl. [Between parental rights and best interests of the child] In J. Ecarius (Ed.), Handbuch Familie [Handbook Family] (pp. 614-636). Wiesbaden: VS.

Bauer, P., \& Wiezorek, C. (2009). Familienbilder professioneller SozialpädagogInnen [Images of the family from professional social workers]. In B. Thiessen \& P. Villa (Eds.), Mütter - Väter: Diskurse, Medien, Praxen [Mothers - Fathers. Discourses, Media, Practices] (pp. 173-193). Münster: Westfälisches Dampfboot.

Bauer, P., Neumann, S., Sting, S., Ummel, H., \& Wiezorek, C. (2015). Familienbilder und Bilder ,guter` Elternschaft. Zur Bedeutung eines konstitutiven, aber vernachlässigten Moments pädagogischer Professionalität [Images of the family and images of a „good“ parenthood. The Importance of a constitutive but unattended moment of the pedagogical professionality]. In S. Fegter, C. Heite, J. Mierendorff, \& M. Richter (Eds.), Neue Praxis, Special Vol. 2014, "Transformationen von Familie und Elternschaft - sozialpädagogische Perspektiven" [Transformations in family and parenthood - pedagogical and social workers' perspectives], 16-28.

Böllert, K. (2012). Die Familie der Sozialen Arbeit [The Family of the Social Work]. In K. Böllert, \& C. Peter (Eds.), Mutter + Vater = Eltern? [Mothers + fathers = parents?] (pp. 117-133). Wiesbaden: Springer; VS.

Bühler-Niederberger, D., Alberth, L., \& Eisentraut S. (2014). Wo bleiben die Kinder im Kinderschutz? Die Logik der Intervention bei Sozialarbeitern, Ärzten und Hebammen [Where are the children in the child protection system? The Logic of the way how Social workers, physicians and midwifes intervene]. In D. Bühler-Niederberger, L. Alberth, \& S. Eisentraut (Eds.), Kinderschutz. Wie kindzentriert sind Programme, Praktiken, Perspektiven? [Child protection. How child-centered are programms, practices and perspectives?] (pp. 26-61). München: Juventa.

Dekker, J. J. H. (2010). Educational Ambitions in History. Childhood and Education in an Expanding Educational Space from the Seventeenth to the Twentieth Century. Frankfurt am Main: Peter Lang. Featherstone, B., Morris, K., \& White, S. (2014). A Marriage Made in Hell: Early Intervention Meets Child Protection. British Journal of Social Work, 44(7), 1-15.

Hall, C., \& Slembrouck, S. (2011). Interviewing parents of children in care: perspectives, discourse and accountability. Children and Youth Services Review, 33(3), 457-465.

Hasselhorn, M., Andresen, S., Becker, B., Betz, T., Leuzinger-Bohleber, M., \& Schmid, J. (2015). 
Children at Risk of Poor Educational Outcomes: In Search of a Transdisciplinary Theoretical Framework. Child Indicators Research, 8(2), 425-438.

Helming, E. (2010). Kontrollstrategien der Kinder- und Jugendhilfe am Beispiel der Entwicklung von Frühwarnsystemen und Frühen Hilfen [The development of early warning systems and early support as examples for control strategies in Youth welfare]. In B. Michel-Schwartze (Ed.), „Modernisierungen“ methodischen Handelns in der Sozialen Arbeit ["Modernization” of methodical acting in social work] (pp. 173-204). Wiesbaden: Springer; VS.

Helsper, W. (2004). Pädagogisches Handeln in den Antinomien der Moderne [The pedagogical acting in the antinomies of the modern World]. In H. H. Krüger \& W. Helsper (Eds.), Einführung in Grundbegriffe und Grundfragen der Erziehungswissenschaft [Introduction into the basic concepts and basic questions of the educational science] (pp. 15-34). Wiesbaden: UTB.

Hildenbrand, B. (2011). Welches sind günstige Rahmenbedingungen für die ersten Jahre des Aufwachsens? Wie können diese in Einrichtungen öffentlicher Sozialisation gefördert werden? Überlegungen auf der Grundlage eines laufenden Forschungsprojekts [Which are advantageous conditions for the first years of growing up? How can they be supported in public socialization? Considerations based on an ongoing research project]. In G. Robert, K. Pfeifer, \& T. Drößler (Eds.), Aufwachsen in Dialog und sozialer Verantwortung. Bildung - Risiken - Prävention [Growing up in dialogue and social responsibility. Education - risks - prevention] (pp. 21-47). Wiesbaden: Springer; VS. Honig, M. S. (1999). Entwurf einer Theorie der Kindheit [Draft of a theory of childhood]. Frankfurt am Main: Suhrkamp.

Hübenthal, M., \& Ifland, A. M. (2011). Risks for children? Recent developments in early childcare policy in Germany. Childhood 18(1), 114-127.

Lenz, K., \& Böhnisch, L. (1997). Zugänge zu Familien - ein Grundlagentext [Family approaches - a basic text]. In L. Böhnisch, \& K. Lenz (Eds.), Familien. Eine interdisziplinäre Einführung [Families. An interdisciplinary introduction] (pp. 9-63). Weinheim, Munich: Juventa.

Pardo-Puhlmann, M. (2010). „Ich sehe was, was du nicht siehst .... "Der sozialpädagogische Blick auf die Familie - Eine Pilotstudie über Familienbilder von Sozialpädagogen in der Kinder- und Jugendhilfe ['I spy with my little eye...' The social pedagogical views on families - a pilot study on family images of social workers in the child and youth welfare]. Unveröffentlichte Magisterarbeit: FriedrichSchiller-Universität Jena.

Riemann, G. (2010). The Significance of Procedures of Ethnography and Narrative Analysis for the (Self-) Reflection of Professional Work. In R. Bohnsack, N. Pfaff, \& W. Weller (Eds.), Qualitative Analysis and Documentary Method. In International Educational Research (pp. 75-95). Opladen: Barbara Budrich.

Slembrouck, S., \& Hall, C. (2003): 'Caring but not coping.' Fashioning the Legitimate Parent Identity. In Ch. Hall, K. Juhila, N. Parton, \& T. Pösö (Eds.), Constructing Clienthood in Social Work and human Services. Interaction, Identities and Practices. (pp. 44-61). London \& New York: Jessica Kingsley. Turnbull, G., \& Spence, J. (2011). What's at risk? The proliferation of risk across child and youth policy in England. Journal of Youth Studies, 14(8), 939-959. 
Ummel, H., Bauer P., \& Wiezorek C. (2013). Das Verschwinden der strukturellen Besonderheit von Familie im Familienbild einer Professionellen aus dem frühpädagogischen Bereich.

Überlegungen zur Entdifferenzierung von öffentlicher und privater Erziehung [The disappearance of the structural family characteristics in the family image of a professional in the field of early education. Considerations of de-differentiations in public and private education]. In Sektion Sozialpädagogik und Pädagogik der frühen Kindheit (Eds.), Konsens und Kontroversen [Consensus and Controversies] (pp. 139-168). Weinheim: Beltz Juventa.

Urek, M. (2005). Making a Case in Social Work. Qualitative Social Work, 4(4), 451-467

White, S. (2003). The Social Worker as Moral Judge: Blame, Responsibility and Case Formulation. In C. Hall, K. Juhila, N. Parton, \& T. Pösö (Eds.), Constructing Clienthood in Social Work and Human Services. Interaction, Identities and Practices (pp. 177-192). London/New York: Jessica Kingsley. White, S., \& Wastell, D. (2011). Theoretical vocabularies and moral negotiation in child welfare: The saga of Evie and Seb. In C. N. Candlin, \& S. Sarangi (Eds.), Handbook of Communication in Organisations and Professions (pp. 259-276). Berlin \& Boston: De Gruyter Mouton.

Wiezorek, C., \& Pardo-Puhlmann, M. (2013). Armut, Bildungsferne, Erziehungsunfähigkeit - Zur Reproduktion sozialer Ungleichheit in pädagogischen Normalitätsvorstellungen [Poverty, little access to education, educational disability - about the reproduction of social inequality in pedagogical normality beliefs]. In F. Dietrich, M. Heinrich, \& N. Thieme (Eds.), Bildungsgerechtigkeit jenseits von Chancengleichheit [Educational justice beyond equal opportunities] (pp. 197-214). Berlin \& Wiesbaden: Springer; VS.

Wilhelm, E. (2005). Rationalisierung der Jugendfürsorge. Die Herausbildung neuer Steuerungsformen des Sozialen zu Beginn des 2o. Jahrhunderts [Rationalization of the youth care. The development of new forms of social regulation at the beginning of the 2 oth century]. Bern: Haupt.

Zenz, G. (1979). Kindesmißhandlung, Kinderschutz und Kindesrechte im geschichtlichen Überblick [Child abuse, child protection and children's rights in a historical view]. In G. Zenz (Ed.), Kindesmißhandlung und Kindesrechte. Erfahrungswissen, Normstruktur und Entscheidungsrationalität [Child abuse and children's rights. Know-how, norm patterns and logical reasoning in decision making] (pp. 19-76). Frankfurt am Main: Suhrkamp. 


\section{Biographical note}

Since 2009 Petra BAuer is Professor of Educational Science at the Institute of Education (Department of Social Pedagogy and Social Work) at the Eberhard-Karls-Universität Tübingen. Before she worked as Scientific Assistant at the Freie Universität Berlin and at the Friedrich-Schiller-Universität Jena. Her research interests are counselling and supervision, interprofessional collaboration and institutional networking and the professional relationship between families and social worker.

Since 2013 Christine Wiezorek is Professor of Educational Science with focus of pedagogy of adolescence at the University of Gießen. From 2007 to 2012 she held an interim professorship at the Institute of Educational Science, University of Jena. Before that she worked as a research assistant at the Institute of Educational Science at the University of Jena and at the Center for School and Educational Research at the University of Halle. She studied Educational Science (diploma) at the Free University of Berlin. 